Article

\title{
Response of Multi-Incidence Angle Polarimetric RADARSAT-2 Data to Herbaceous Vegetation Features in the Lower Paraná River Floodplain, Argentina
}

\author{
Natalia Soledad Morandeira 1,2,*(D), Matías Ernesto Barber ${ }^{2,3}$, Francisco Matías Grings ${ }^{2,3}$, Frank Ahern 4 , \\ Patricia Kandus ${ }^{1}$ and Brian Brisco ${ }^{5}$ (D) \\ 1 Instituto de Investigación e Ingeniería Ambiental, Universidad Nacional de San Martín, 25 de Mayo and \\ Francia S/N, General San Martín 1650, Buenos Aires, Argentina; pkandus@unsam.edu.ar \\ 2 Consejo Nacional de Investigaciones Científicas y Técnicas (National Scientific and Technical Research \\ Council, CONICET), Ciudad Autónoma de Buenos Aires 1425, Argentina; mbarber@iafe.uba.ar (M.E.B.); \\ verderis@iafe.uba.ar (F.M.G.) \\ 3 Instituto de Astronomía y Física del Espacio, Universidad de Buenos Aires-CONICET, \\ Ciudad Autónoma de Buenos Aires 1428, Argentina \\ 4 TerreVista Earth Imaging, Hamilton, ON L8P 4V4, Canada; 3C279@cogeco.ca \\ 5 Canada Centre for Mapping and Earth Observation, Natural Resources Canada, \\ Ottawa, ON K1A 1M1, Canada; brian.brisco@canada.ca \\ * Correspondence: nmorandeira@unsam.edu.ar
}

check for updates

Citation: Morandeira, N.S.; Barber, M.E.; Grings, F.M.; Ahern, F.; Kandus, P.; Brisco, B. Response of

Multi-Incidence Angle Polarimetric RADARSAT-2 Data to Herbaceous Vegetation Features in the Lower Paraná River Floodplain, Argentina. Remote Sens. 2021, 13, 2518. https:// doi.org $/ 10.3390 /$ rs 13132518

Academic Editor: Francesco Mattia

Received: 5 May 2021

Accepted: 21 June 2021

Published: 27 June 2021

Publisher's Note: MDPI stays neutral with regard to jurisdictional claims in published maps and institutional affiliations.

Copyright: (c) 2021 by the authors. Licensee MDPI, Basel, Switzerland. This article is an open access article distributed under the terms and conditions of the Creative Commons Attribution (CC BY) license (https:// creativecommons.org/licenses/by/ $4.0 /)$.
Abstract: Wetland ecosystems play a key role in hydrological and biogeochemical cycles. In emergent vegetation targets, the occurrence of double-bounce scatter is indicative of the presence of water and can be valuable for hydrological monitoring. Double-bounce scatter would lead to an increase of $\sigma^{0} \mathrm{HH}$ over $\sigma^{0} \mathrm{VV}$ and a non-zero co-polarized phase difference (CPD). In the Lower Paraná River floodplain, a total of 11 full polarimetric RADARSAT-2 scenes from a wide range of incidence angles were acquired during a month. Flooded targets dominated by two herbaceous species were sampled: Schoenoplectus californicus (four sites, Bulrush marshes) and Ludwigia peruviana (three sites, Broadleaf marshes). As a general trend, $\sigma^{0} \mathrm{HH}$ was higher than $\sigma^{0} \mathrm{VV}$, especially at the steeper incidence angles. By modeling CPD with maximum likelihood estimations, we found results consistent with doublebounce scatter in two Ludwigia plots, at certain scene incidence angles. Incidence angle accounted for most of the variation on $\sigma^{0} \mathrm{HH}$, whereas emergent green biomass was the main feature influencing $\sigma^{0} \mathrm{HV}$. Multivariate models explaining backscattering variation included the incidence angle and at least two of these variables: emergent plant height, stem diameter, number of green stems, and emergent green biomass. This study provides an example of using CPD to decide on the contribution of double-bounce scatter and highlights the influence of vegetation biomass on radar response. Even with the presence of water below vegetation, the contribution of double-bounce scatter to C-band backscattering depends on scene incidence angles and may be negligible in dense herbaceous targets.

Keywords: active microwave; C-band; co-polarized phase difference; double-bounce scatter; flooded marshes; incidence angle; macrophytes; Paraná River Delta; polarimetry; wetland

\section{Introduction}

Wetland ecosystems play a key role in hydrological and biogeochemical cycles and comprise a large part of the world's biodiversity and resources [1]. South America is the continent with the largest surface covered by wetlands $(>20 \%$, [1]), with the greatest extension being covered by fluvial wetlands associated with the Amazonas, the Orinoco, and the Paraguay-Paraná rivers [2]. Floodplain wetlands are complex macrosystems with mosaics of different wetland types dominating the landscape [3]. These ecosystems' dynamics are mainly controlled by flood pulses, which determine fluxes of materials 
and organisms between the river and the floodplain, influence ecological processes, and promote connectivity of floodplain water bodies $[4,5]$.

Due to the large extension of fluvial wetlands and their restricted accessibility, the use of remote sensing data can contribute substantially to inventory and monitoring procedures at broad ecological scales (continental, regional, or landscape scales). The capabilities of optical imagery to discriminate vegetated wetland targets and to detect flooded areas is limited. The high biomass of herbaceous plants often saturates the signal and leads to high confusion errors between vegetation types [6] and between vigorous rooted vegetation and macrophytes floating on shallow lakes [7]. Synthetic Aperture Radar (SAR) measurements are sensitive to soil and plant moisture, to soil roughness, and to plant architecture, and can also detect the presence of water below the vegetation, providing critical information for vegetation target discrimination and water resource management [8]. Moreover, SAR data can get accurate information even in the presence of clouds or smoke [9].

The high return in backscattered power in flooded wetlands has been attributed to the double-bounce backscattering mechanism $[9,10]$. The presence of water below vegetation with vertical stems is a typical case for which the contribution of double-bounce scatter to backscattered signal is expected $[9,11]$. This return has been well described for flooded Amazonian forests [12,13] and for swamps and marshes [8,14]. Additionally, backscattering has been modeled for herbaceous bulrushes and sedges in the Paraná River floodplain $[15,16]$, but no polarimetric information was included.

Several of the herbaceous vegetation types that occur in wetlands dominate over large areas. On extended targets comprised of vegetation with cylinder-like stems emerging from a water surface, co-polarized (HH and VV) response is due to a combination of single (odd-) bounce backscatter directly off stems, branches, or leaves, and water-vegetation double-bounce backscatter; whereas the cross-polarized backscatter (HV) can arise from coherent scattering by tilted cylindrical structures [17] as well as from multiple-bounce (volume) scattering by the vegetation's bulk [18-20]. As for HV, it increases as the emergent biomass increases. Additionally, double-bounce backscattering implies an increase of $\mathrm{HH}$ over VV and a non-zero co-polarized phase difference. Indeed, the scattering events related to the wave's propagation through the vegetation bulk, to the reflection off the underlying water surface and to the specular bistatic reflection by the stems combine to change the relative phase difference between co-polarized (HH-VV) measurements (copolarized phase difference, hereafter named CPD). Therefore, this phase information might decide whether double bounce (non-zero phase difference) or single direct bounce (nearly zero) is the main contributor to the backscatter response [21,22].

Although polarimetric decompositions are widely used to describe the contribution of interaction mechanisms, recent studies have addressed anomalous results in flooded marshes, mangroves, and swamps: even for high backscattering power, decompositions have indicated a dominant contribution of odd-bounce mechanism [22-24]. Based on these unexpected results and on analyses of temperate wetlands at C-band, it has been suggested that double-bounce scatter varies as a function of the incidence angle [22]. Additionally, changes in the Fresnel reflection coefficients (i.e., the ratio of the received to transmitted electric field strength, which depends on the incidence angle and on the refractive indices of the incident and refracting media) at the Brewster angle have been proposed and modeled $[14,21,25,26]$ : this particular Brewster angle, at which there is no reflection in vertically polarized radiation [27], needs to be considered when interpreting polarimetric data. At the Brewster angle, VV reflectivity reaches a minimum and the co-polarized phase changes are most rapid [14]. In dihedral models, with double-bounce occurring, a double Brewster angle effect has been described [25]: the resulting output is $\mathrm{HH}$ backscattering much higher than VV backscattering. Thus, determining the contribution of the interaction mechanisms or the presence of double-bounce scatter from polarimetric decompositions (e.g., [28,29]) is a limited approach [14]. Instead, these recent studies emphasize that assessing CPD distributions can improve our understanding of the interaction between the SAR signal and wetland targets, and CPD has been proposed as a diagnostic criterion 
of double-bounce scatter [22]. In targets with no significant symmetry rotation, crosspolarized (HH-HV or VV-HV) phase difference distributions can also be informative of scattering mechanisms (cross-polarized phase difference, hereafter named XPD) [26,30].

This study addressed the interaction between C-band SAR signal and herbaceous targets in a temperate-humid fluvial wetland, the Lower Paraná River floodplain (also known as Paraná River Delta). These wetlands have previously been classified with C-band and X-band data [31,32], but the phase difference response was not explicitly addressed, nor explicit models between SAR signal and vegetation features. Our aims were: (a) to assess the relation between backscattering power and phase differences, and to study how they vary with incidence angles; and (b) to evaluate the effect of vegetation features on backscattering power. RADARSAT-2 scenes from a wide range of incidence angles (beams FQ-2 to FQ-29, mean angles $20.7^{\circ}$ to $47.4^{\circ}$ ) were acquired over one month. In February 2018 we sampled plots from two dominant herbaceous targets with different architectures, Schoenoplectus californicus and Ludwigia peruviana. These two species dominate extensive Bulrush marshes and Broadleaf marshes, respectively, in the Lower Paraná River floodplain [33]. We analyzed whether double-bounce scatter occurred and discussed the backscatter dependence on SAR incidence angle and vegetation features.

\section{Materials and Methods}

\subsection{Study Area}

The study area is a sector of the Lower portion of the Paraná River floodplain, which runs $400 \mathrm{~km}$ South-Southeast along Argentina's main populated and industrial area (Figure 1). In this zone, the floodplain reaches 10 to $30 \mathrm{~km}$ wide and emergent macrophytes dominate. The climate is temperate humid; mean annual temperature is $17.1^{\circ} \mathrm{C}$. January is the hottest month and July the coldest $\left(24.0^{\circ} \mathrm{C}\right.$ and $10.3^{\circ} \mathrm{C}$, respectively). Mean annual precipitation is $1074 \mathrm{~mm}$, March being the wettest month and August the driest $(126.4 \mathrm{~mm}$ and $42.1 \mathrm{~mm}$, respectively) (1965-2019, Instituto Nacional de Tecnología Agropecuaria at $\left.33^{\circ} 44^{\prime} \mathrm{S} 59^{\circ} 41^{\prime} \mathrm{W}\right)$.

Natural forests occur in reduced areas covering up to $6 \%$ of the Lower Paraná River floodplain, and are mainly located at high elevations such as levees or river banks [34]. Emergent macrophytes plant communities cover more than $90 \%$ of the wetland area, dotted by shallow lakes and secondary rivers and streams, and are usually dominated by one or very few species $[33,35,36]$. Macrophytes have high productivity, are an input of organic carbon, provide habitats for wildlife and fish, and are essential for flood regulation. Several herbaceous plant communities differing in their structure and functions were described, including marshes, grasslands, salt marshes, broadleaf marshes, bulrush marshes, floating meadows, and scrublands [33].

Bulrush marshes dominated by Schoenoplectus californicus (C.A. Mey.) Soják (Cyperaceae) and Broadleaf marshes dominated by Ludwigia peruviana (L.) H. Hara (Onagraceae) are two of the typical plant communities in the Lower Paraná River floodplain (especially in the Middle Delta) [33]. Although these marshes have a relatively low taxonomic diversity [36], they cover large areas with generally high plant biomass, having a significant effect on the ecosystem functioning of the floodplain. Preserving a mosaic of these and other marshes promotes biodiversity at a landscape scale [36]. Bulrush and Broadleaf marshes also contribute to sustaining the regional economy by providing nursery areas for commercial fishing and forage for cattle grazing [37]; and Ludwigia species are usually part of the bee flora [38]. 


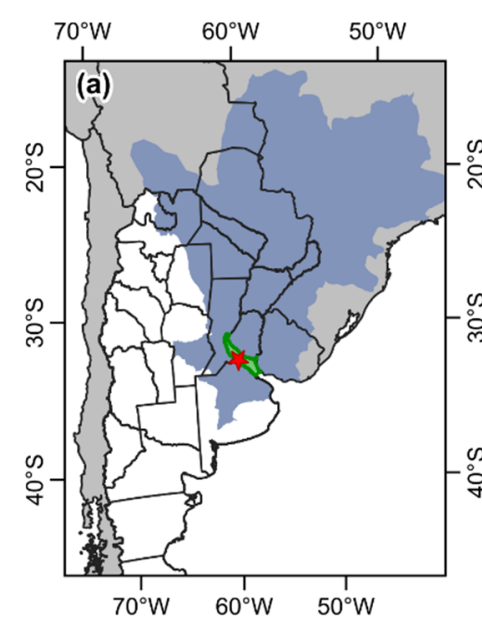

\section{References}
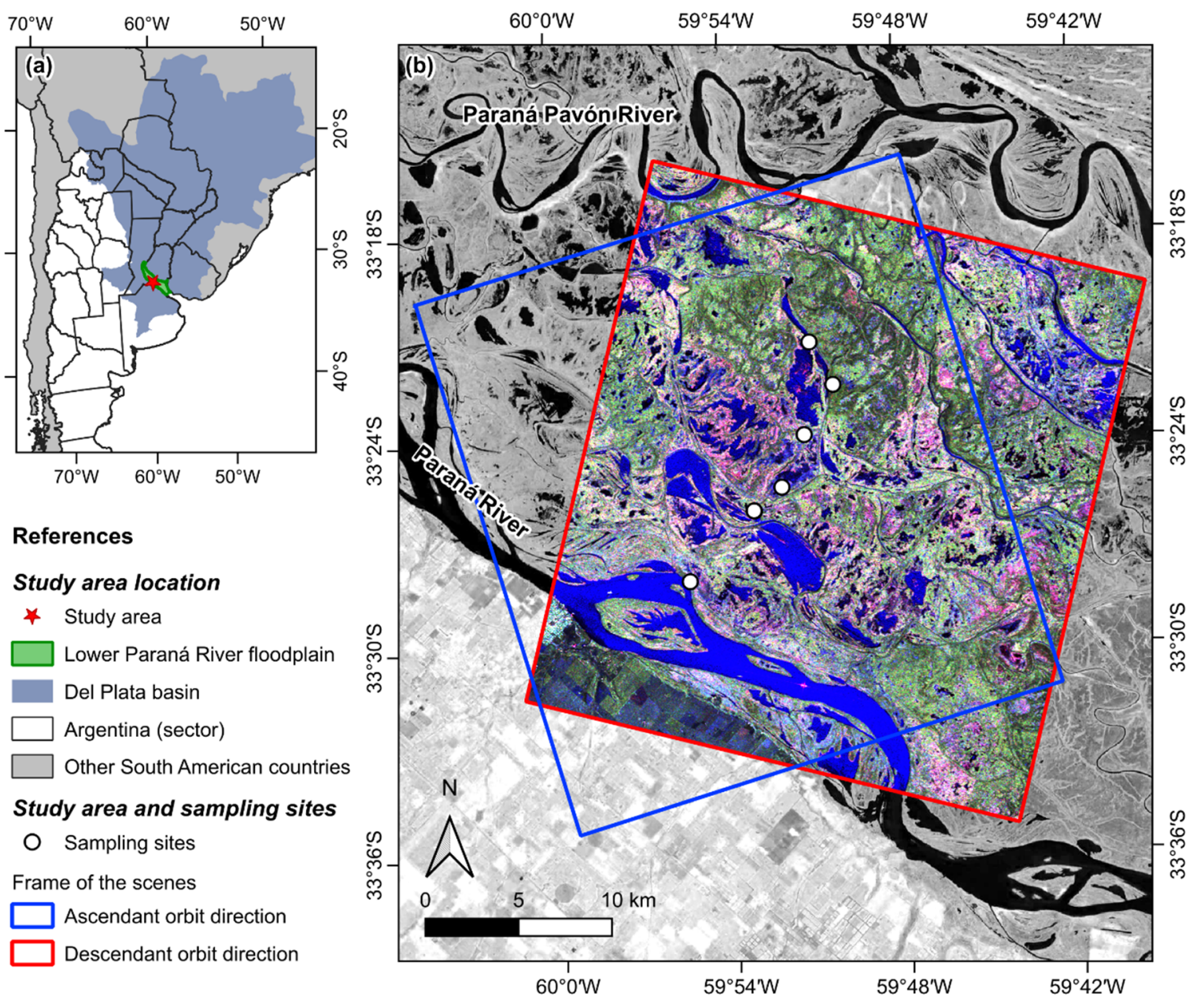

Figure 1. Study area at the Lower Paraná River floodplain. (a) Location in the Del Plata basin and the Lower Paraná River floodplain. (b) Sampling sites. A RADARSAT-2 scene acquired on 6 February 2018 is shown (FQ 2, Pauli representation: $\mathrm{R}=\left|S_{\mathrm{HH}}-S_{\mathrm{VV}}\right|^{2} ; \mathrm{G}=2\left|S_{\mathrm{HV}}\right|^{2} ; \mathrm{B}=\left|S_{\mathrm{HH}}+S_{\mathrm{VV}}\right|^{2}$ ); with a Landsat 8-OLI background scene (near infrared band in grayscale), acquired on 19 January 2018.

\subsection{Field Sampling}

Field sampling was conducted in February 2018, in flooded sites dominated by the herbaceous species Schoenoplectus californicus (hereafter named Schoenoplectus) or Ludwigia peruviana (hereafter named Ludwigia) (Figure 1). These species show contrasting architectures (Figure 2). Schoenoplectus is a bulrush, with no leaves and cylindrical stems distributed almost vertically. Ludwigia is a broadleaf herb, and usually has a main stem with branches and leaves.

Seven almost monospecific sites were selected: four dominated by Schoenoplectus and three by Ludwigia. These sites were georeferenced. In each site, two plots were sampled. Vegetation censuses were conducted in $1 \mathrm{~m}^{2}$ plots by means of a Braun-Blanquet scale, to estimate plant abundance-coverage and address the potential accompanying species [39]. To illustrate plant sizes and stem angles, photographs were taken with a grid behind the vegetation (see Figure 2). In each plot, three records of the photosynthetically active radiation (PAR) above and below vegetation were obtained with a $1 \mathrm{~m}$ linear quantum sensor (Cavadevices BAR-RAD 100); and the average PAR intercepted fraction was computed (fPAR). Water level and vegetation features were measured in a $25 \mathrm{~cm} \times 25 \mathrm{~cm}$ area: number of stems, stem diameters, emergent plant height, plant moisture content, and emergent biomass. To estimate biomass and moisture, vegetation was harvested, and the fresh weight was recorded with a field scale. In the laboratory, harvests were separated per species and green/dry portions. Samples were dried at $60^{\circ} \mathrm{C}$ for $72 \mathrm{~h}$ and dry weight was 
measured. Emergent green biomass $\left(\mathrm{g} \cdot \mathrm{m}^{-2}\right)$ and gravimetric moisture content $(\%)$ were estimated for Schoenoplectus and Ludwigia. Vegetation variables were averaged on the two plots of each site.
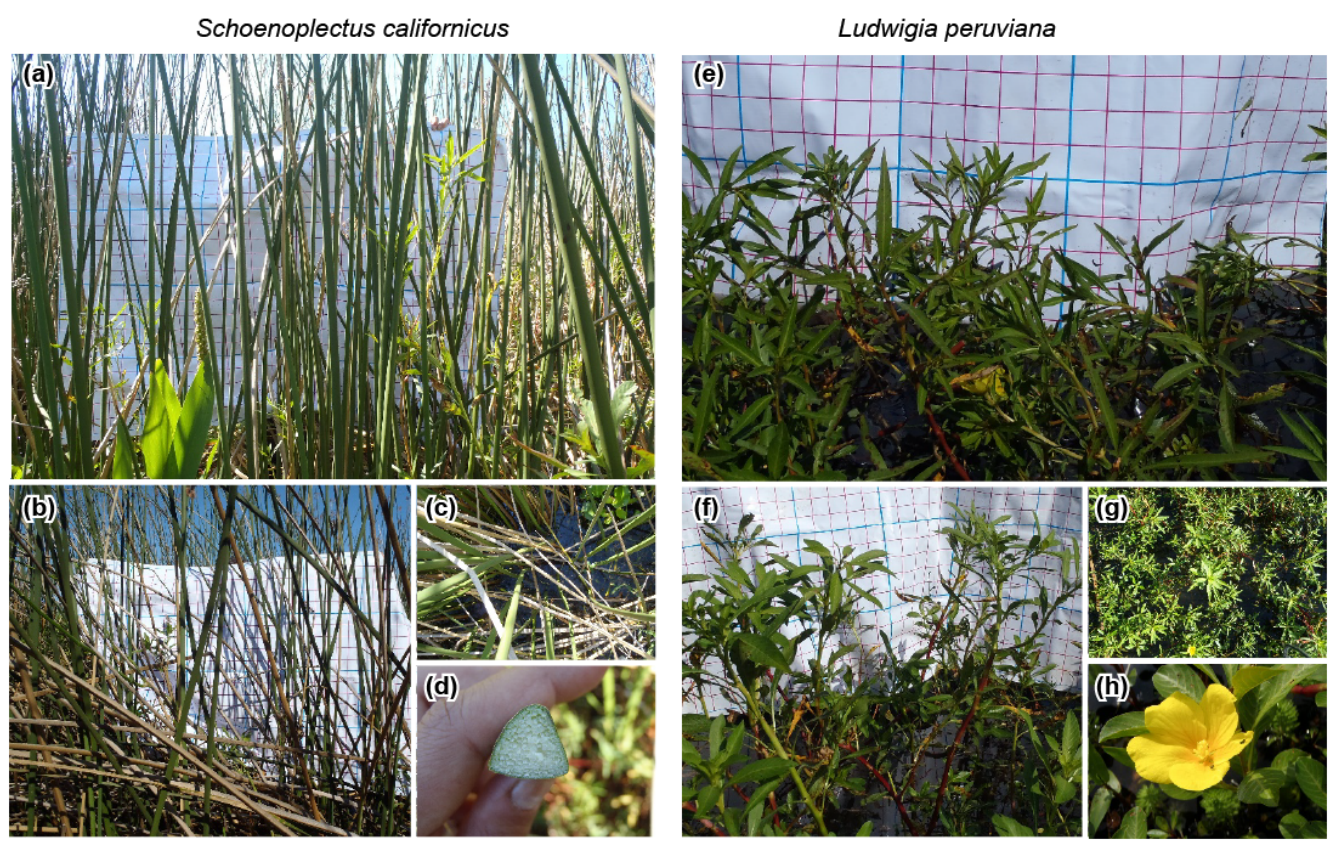

Figure 2. Representative photographs of the sampled targets and dominant species: Schoenoplectus californicus and Ludwigia peruviana. For Schoenoplectus: (a,b) two of the sampled sites, with vertical and tilted stems, showing some accompanying species in (a) and the presence of dry stems in (b); (c) top view of a Schoenoplectus site, showing the presence of water; (d) stem cross-section, with high proportion of aerenchyma. For Ludwigia: (e,f) two of the sampled sites, with vertical and tilted stems, and broad leaves; (g) top view of a Ludwigia site, showing the presence of water; (h) detail of flower and leaves. In subfigures $(\mathbf{a}, \mathbf{b}, \mathbf{e}, \mathbf{f})$, a $150 \mathrm{~cm} \times 100 \mathrm{~cm}$ grid was used: space between magenta lines was $5 \mathrm{~cm}$ and space between cyan lines was $25 \mathrm{~cm}$. Grid colors were chosen to contrast vegetation. See the electronic version for color images.

\subsection{Scene Acquisition and Processing}

A total of 11 full polarimetric RADARSAT-2 C-band scenes were acquired in February 2018, differing in their orbit direction and beams (FQ5 to FQ29, mean incidence angles between $20.7^{\circ}$ and $47.4^{\circ}$ ) (Table 1 ). RADARSAT-2 is a SAR satellite mission of the Canadian Space Agency and MacDonald, Dettwiler and Associates, operating at a $5.405 \mathrm{GHz}$ frequency. In the Fine Resolution Quad-polarization beam (FQ), scenes have a nominal swath of nominal swath width of $25 \mathrm{~km}$ and a resolution of $5.2 \mathrm{~m}$ (range) $\times 7.6 \mathrm{~m}$ (azimuth). The system repeat pass is of 24 days (same sensor mode and geometry); but our acquisition plan covered 11 scenes in 24 days-varying incidence angles, see Table 1.

Scenes were acquired in Single Look Complex (SLC) processing type and were calibrated to the coherence matrix (slant range geometry). Additionally, multilooking was applied ( 6 pixels in azimuth $\times 3$ pixels in range) and coherence matrices were geocoded to a $12.5 \mathrm{~m} \times 12.5 \mathrm{~m}$ pixel by means of linear resampling (ground range geometry). Based on the sampling sites' georeferenced position, regions of interest (ROIs) were drawn on ground-range geocoded SAR imagery, aided with optical imagery from close acquisition dates (Sentinel-2 and SPOT-6). The components of the complex covariance matrix (C3) were extracted for each ROI, and single polarization backscattering coefficients $\left(\sigma^{0} \mathrm{HH}\right.$, $\sigma^{0} \mathrm{HV}, \sigma_{\mathrm{VV}}^{0}$ ), CPD and XPD were derived (with XPD defined as HH-HV phase difference). Multilooking substantially decreased the number of pixels per ROI, hindering the analysis of CPD and XPD distributions. To circumvent this issue, we projected back the ROIs onto the C3 matrices on slant range geometry (reverse geolocation, see $[40,41]$ ), and CPD 
and XPD were re-extracted. After checking that median values and histogram shapes were conserved in both geometries, we decided to use CPD and XPD extracted on slant range data (with a higher number of pixels than ground range data) for fitting purposes. Software PolSARpro [42] and SNAP [43] were used to process the scenes and extract data on the ROIs.

Table 1. List of RADARSAT-2 scenes. Wind data corresponds to 6 AM and 8 PM records (local time) for scenes acquired with descending and ascending orbit directions, respectively (Rosario city station, $32^{\circ} 58^{\prime} 4.1^{\prime \prime}$ S, $\left.60^{\circ} 39^{\prime} 33.2^{\prime \prime} \mathrm{W}\right)$. In the Figures, scenes 1 and 11 are coded as FQ_10a and FQ_10b.

\begin{tabular}{cccccc}
\hline No. & Date (2018) & Beam & Mean Angle & Orbit Direction & Wind Speed (km/h) \\
\hline 1 & 4 February & FQ 10 & 30.0 & Ascending & 7 \\
2 & 6 February & FQ 2 & 20.7 & Descending & 0 \\
3 & 7 February & FQ 26 & 45.1 & Ascending & 4 \\
4 & 11 February & FQ 5 & 24.4 & Ascending & 11 \\
5 & 13 February & FQ 8 & 27.8 & Descending & 4 \\
6 & 14 February & FQ 21 & 40.9 & Ascending & 11 \\
7 & 17 February & FQ 29 & 47.4 & Descending & 6 \\
8 & 20 February & FQ 13 & 33.2 & Descending & 11 \\
9 & 21 February & FQ 16 & 36.2 & Ascending & 11 \\
10 & 27 February & FQ 18 & 38.2 & Descending & 9 \\
11 & 28 February & FQ 10 & 30.0 & Ascending & 11 \\
\hline
\end{tabular}

During the acquisition period, the hydrometric level measured at a water gauge on the Paraná River was similar and relatively low, and precipitation was not substantial (Figure 3). Wind speed at the time of the acquisitions ranged between 0 and $11 \mathrm{~km} \cdot \mathrm{h}^{-1}$, i.e., wind conditions were "calm" to "gentle breeze". Based on this information, and provided that vegetation growth was negligible during February 2018, we assumed that backscattering changes between scenes were mostly related to incidence angles.

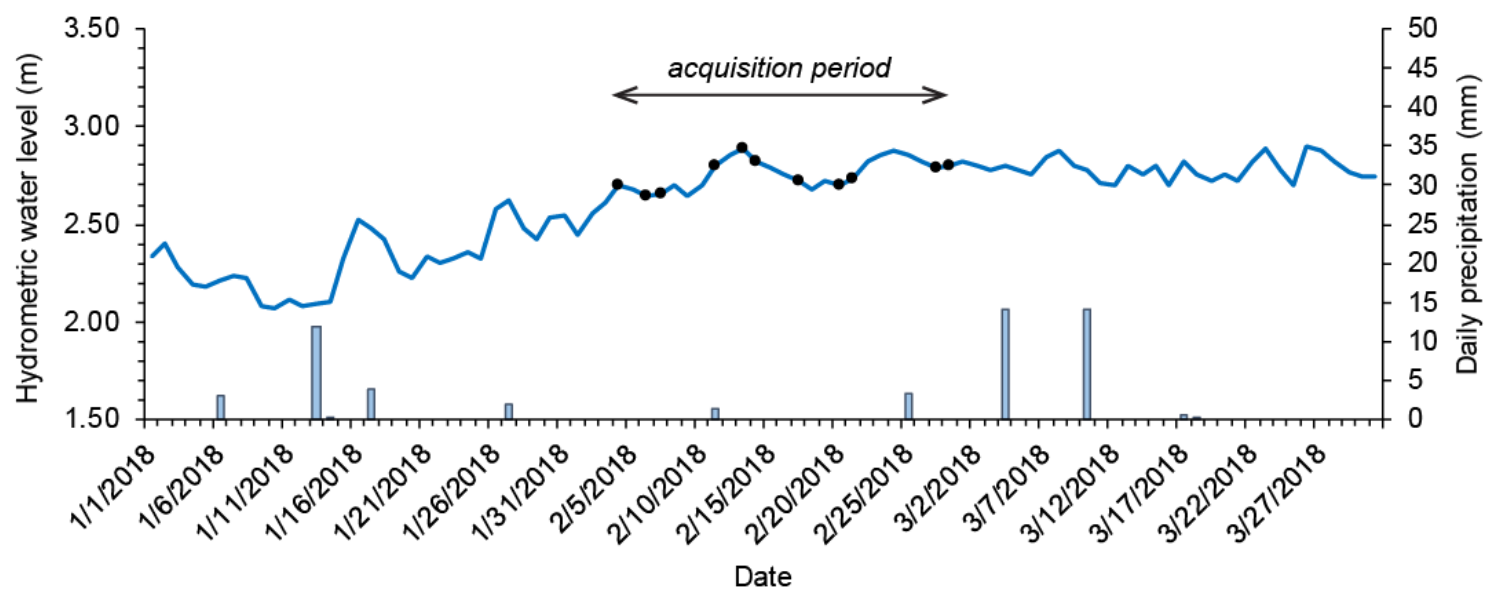

Figure 3. Hydrometric water level measured in the Paraná River (Ramallo city water gauge $33^{\circ} 29^{\prime} 4.8^{\prime \prime} \mathrm{S}, 60^{\circ} 0^{\prime} 20.8^{\prime \prime} \mathrm{W}$; plotted with lines) and daily precipitation measured (Rosario city station, 32 $58^{\prime} 4.1^{\prime \prime} \mathrm{S}, 60^{\circ} 39^{\prime} 33.2^{\prime \prime}$ W; plotted with bars). Days with RADARSAT-2 scene acquisitions are pointed out by dots (see scene list in Table 1).

\subsection{Single Polarization and Phase Difference Analyses}

The backscattering coefficients at single polarizations ( $\mathrm{HH}, \mathrm{HV}$, and $\mathrm{VV}$ ) were explored with boxplots and scatter plots, and further assessed using generalized linear models [44]. Analyses were performed on a species-basis (Schoenoplectus and Ludwigia). Since no significant differences were observed between ascending and descending orbit directions, data was analyzed and discussed together. 
Estimations of the CPD and XPD two-parameter distribution were computed as follows. With fully polarimetric SAR data acquired with phase-calibrated images, such as that from RADARSAT-2, the derivation of an absolute co-polarized phase difference $\psi$ is given by:

$$
\mathrm{CPD}=\psi=\phi_{\mathrm{HH}}-\phi_{\mathrm{VV}}=\arg \left(S_{\mathrm{HH}} S_{\mathrm{VV}}^{*}\right)
$$

where $S_{\mathrm{HH}}$ and $S_{\mathrm{VV}}$ are the $\mathrm{HH}$ and $\mathrm{VV}$ complex amplitudes and ${ }^{*}$ denotes complex conjugate. In terms of the $\mathrm{C} 3$ matrix, $S_{\mathrm{HH}} S_{\mathrm{VV}}^{*}$ is the element $\mathrm{C}_{13}$. The statistical distribution of $\psi$ for a 1-look speckled image is known and its closed-form expression is [45]:

$$
p_{\psi}=\frac{\left(1-\left|\rho_{c}\right|^{2}\right)\left[\left(1-\beta^{2}\right)^{\frac{1}{2}}+\beta\left(\pi-\cos ^{-1}(\beta)\right)\right]}{2 \pi\left(1-\beta^{2}\right)^{3 / 2}}-\pi \leq \psi<\pi
$$

where

$$
\beta=\left|\rho_{c}\right| \cos \left(\psi-\psi_{0}\right)
$$

The phase difference distribution $p_{\psi}$ is unimodal, symmetric and modulus $2 \pi$ about its mode, which occurs at $\psi_{0}$. As Equations (2) and (3) show, the phase difference distribution depends on the coherence $\left|\rho_{c}\right|$. For a coherence close to 1 , the distribution resembles a delta function located at $\psi_{0}$; whereas for a coherence close to zero, the distribution is very close to a uniform distribution [45].

In Equations (2) and (3), the parameters $\psi_{0}$ and $\left|\rho_{c}\right|$ will be estimated from the 1-look histogram from measured $\psi$ by means of a Maximum Likelihood Estimation (MLE) [46] using Equation (2) as the likelihood function to be maximized. Thus, the co-polarized phase difference estimator $\psi_{0}$ is estimated for each sampling site on each acquisition day.

Analogously to CPD, XPD is given by:

$$
\mathrm{XPD}=\phi_{\mathrm{HH}}-\phi_{\mathrm{HV}}=\arg \left(S_{\mathrm{HH}} S_{\mathrm{HV}}^{*}\right)
$$

where $S_{\mathrm{HH}} S_{\mathrm{HV}}^{*}$ is the element $\mathrm{C}_{23}$ of the $\mathrm{C} 3$ matrix.

\subsection{Effects of Vegetation Features on Backscattering Coefficients}

To assess the relation between in situ obtained vegetation measures and SAR variables, generalized linear models (GLM) were conducted [44]. The median values of the backscattering coefficients at $\mathrm{HH}, \mathrm{HV}$, and VV were computed for each ROI and scene, as well as the mean scene incidence angle. Explanatory variables (vegetation features) were averaged per each of the plots, and then centered by subtracting the variable mean and scaled by their standard deviations. All the univariate models were addressed for each species and polarization ( $\mathrm{HH}, \mathrm{HV}$, or $\mathrm{VV})$. Next, multiple models were fitted, and the best models were selected with a manual upward stepwise multiple regression procedure. Each term addition was evaluated based on a significant reduction $(>2)$ in the Akaike's information criterion (AIC) [44]; provided that all terms were significant, with a $p$-value lower than 0.05. A bootstrap procedure with 1000 permutations was performed on the regression coefficients: those coefficients for which the $95 \%$ confidence interval included the zero were removed [47]. To avoid collinearity, models were restricted to have variance inflation factors $<3$ for all the variables [48]. To discard overdispersion, we checked the ratios between residual deviance and degrees of freedom were lower than 1.5. The residual to null deviance ratio was used as an estimator of the model's explanatory power. The distribution of the model residuals was tested to assess normality and homoscedasticity assumptions.

Data preparation, plots, tests and modelling were performed in R [49] with the packages dplyr [50], tidyr [51], ggplot2 [52], lmtest [53], car [54], and boot [55].

\section{Results}

Target features are summarized in Table 2. The seven sites were characterized by a dominance of Schoenoplectus californicus (Sch-1 to Sch-4) or Ludwigia peruviana (Ludw-1 to 
Ludw-3). To facilitate the interpretation of further results, sites dominated by the same species were numbered by increasing emergent green biomass (Table 2). The emergent green biomass of the dominant species represented 56 to $100 \%$ of the total biomass (green + dry portions) (mean $78 \%$ ); whereas the total biomass of the dominant species accounted for 64 to $100 \%$ of the total biomass of the vegetation stand (mean 95\%). Based on this high dominance, each of the sampling sites can be regarded as a homogeneous target.

Table 2. Characterization of the sampling sites dominated by Schoenoplectus californicus or Ludwigia peruviana. Site features include: accompanying species, water level, intercepted fraction of photosynthetically active radiation (fPAR) light, and estimated Braun-Blanquet coverage. All the accompanying species had very low abundance-coverage, except for a floating species $\left(^{*}\right)$ accounting for $40 \%$ coverage below one of the S. californicus stands. Vegetation features of the dominant species include: number of stems, emergent green and total biomass, maximum and mean emergent height, mean stem diameter, and moisture content of the green portion.

\begin{tabular}{|c|c|c|c|c|c|c|c|}
\hline \multirow{2}{*}{$\begin{array}{c}\begin{array}{c}\text { Dominant } \\
\text { Species }\end{array} \\
\text { Sampling site }\end{array}$} & \multicolumn{4}{|c|}{ Schoenoplectus californicus } & \multicolumn{3}{|c|}{ Ludwigia peruviana } \\
\hline & Sch-1 & Sch-2 & Sch-3 & Sch-4 & $L u d w-1$ & $L u d w-2$ & $L u d w-3$ \\
\hline $\begin{array}{c}\text { Accompanying } \\
\text { species }\end{array}$ & $\begin{array}{l}\text { - Emergent: } \\
\text { Ludwigia } \\
\text { peruviana, } \\
\text { Panicum } \\
\text { elephantipes, } \\
\text { Polygonum } \\
\text { punctatum, } \\
\text { Mikania } \\
\text { micrantha, } \\
\text { Solanum } \\
\text { amigdallyfolium. }\end{array}$ & $\begin{array}{l}\text { - Emergent: } \\
\text { Pontederia cordata, } \\
\text { Eichhornia } \\
\text { crassipes, } \\
\text { Ludwigia } \\
\text { peruviana, } \\
\text { Oplismenopsis } \\
\text { najada, Sagittaria } \\
\text { montevidensis. } \\
\text { - Floating: Azolla } \\
\text { filiculoides. }\end{array}$ & $\begin{array}{l}\text { - Emergent: } \\
\text { Ludwigia } \\
\text { peruviana, } \\
\text { Polygonum } \\
\text { acuminatum. } \\
\text { - Floating: } \\
\text { Salvinia biloba (*); } \\
\text { Salvinia } \\
\text { auriculata, Azolla } \\
\text { filiculoides, } \\
\text { Nymphoides } \\
\text { indica. } \\
\text { - Submerged: } \\
\text { Ceratophyllum } \\
\text { demersum. }\end{array}$ & $\begin{array}{l}\text { - Emergent: } \\
\text { Ludwigia } \\
\text { peruviana, } \\
\text { Ludwigia } \\
\text { peploides, } \\
\text { Echinochloa } \\
\text { helodes, } \\
\text { Eichhornia } \\
\text { crassipes. } \\
\text { - Floating: Azolla } \\
\text { filiculoides. }\end{array}$ & $\begin{array}{c}\text { - Emergent: } \\
\text { Oplismenopsis } \\
\text { najada, } \\
\text { Myriophyllum } \\
\text { aquaticum, } \\
\text { Luziola peruviana. } \\
\text { - Floating: Azolla } \\
\text { filiculoides. }\end{array}$ & $\begin{array}{l}\text { - Emergent: } \\
\text { Myriophyllum } \\
\text { aquaticum. } \\
\text { - Floating: } \\
\text { Salvinia } \\
\text { auriculata, } \\
\text { Nymphoides } \\
\text { indica. }\end{array}$ & $\begin{array}{l}\text { - Emergent: } \\
\text { Ludwigia } \\
\text { peploides, } \\
\text { Echinochloa } \\
\text { helodes, } \\
\text { Myriophyllum } \\
\text { aquaticum, } \\
\text { Eichhornia } \\
\text { crassipes. }\end{array}$ \\
\hline Water level (cm) & 15 & 52 & 120 & 60 & 43 & 55 & 55 \\
\hline $\begin{array}{c}\text { Intercepted fPAR } \\
\text { light }(\%)\end{array}$ & $61-74$ & $74-94$ & NA & $90-99$ & $57-59$ & NA & $29-59$ \\
\hline $\begin{array}{c}\text { Estimated } \\
\text { coverage of the } \\
\text { emergent } \\
\text { vegetation }(\%)\end{array}$ & 65 & $65-85$ & $65-85$ & 85 & 65 & $65-85$ & $40-85$ \\
\hline No. stems $\mathrm{m}^{-2}$ & $\begin{array}{l}48 \text { green, } \\
32 \text { dry }\end{array}$ & $\begin{array}{l}\text { 64-96 green, } \\
\text { 32-96 dry }\end{array}$ & $\begin{array}{l}\text { 128-208 green, } \\
48 \text { dry }\end{array}$ & $\begin{array}{l}\text { 96-176 green, } \\
208-240 \text { dry }\end{array}$ & 128-144 green & 128-208 green & 112-144 green \\
\hline $\begin{array}{l}\text { Emergent green } \\
\text { biomass }\left(\mathrm{g} \cdot \mathrm{m}^{-2}\right)\end{array}$ & 352 & $912-944$ & $784-1696$ & $2512-2528$ & $176-384$ & $352-384$ & $80-784$ \\
\hline $\begin{array}{l}\text { Emergent total } \\
\text { biomass }\left(\mathrm{g} \cdot \mathrm{m}^{-2}\right)\end{array}$ & 624 & $960-1600$ & $1056-1716$ & $2804-2976$ & $176-384$ & $352-384$ & $80-784$ \\
\hline $\begin{array}{l}\text { Maximum } \\
\text { emergent height } \\
(\mathrm{cm})\end{array}$ & 154 & 226 & 298 & 300 & 80 & 85 & 66 \\
\hline $\begin{array}{c}\text { Mean emergent } \\
\text { height }(\mathrm{cm})\end{array}$ & 119 & 156 & 138 & 210.5 & 63 & 37 & 33 \\
\hline $\begin{array}{c}\text { Mean stem } \\
\text { diameter }(\mathrm{mm})\end{array}$ & 11.2 & 10.35 & 10 & 12.76 & 4.3 & 4.2 & 4.5 \\
\hline $\begin{array}{l}\text { Moisture content } \\
(\%)\end{array}$ & 62 & $67-70.1$ & $66-67$ & $72-77$ & $77-80$ & $69-75$ & $75-78$ \\
\hline
\end{tabular}

For the three polarizations, median backscattering coefficients were higher at Ludwigia targets than at Schoenoplectus targets $(p<0.0001)$. The overall trend for median backscattering coefficients was a decrease with incidence angles, both at Schoenoplectus and Ludwigia plots (Figure 4). Regarding co-polarizations, $\sigma^{0} \mathrm{HH}$ was higher than $\sigma^{0} \mathrm{VV}$, especially at steep incidence angles (FQ_02), obtaining $\sigma^{0} \mathrm{HH}_{-} \sigma^{0} \mathrm{VV}$ differences of a maximum of $3.6 \mathrm{~dB}$ (minimum $-1.74 \mathrm{~dB}$, mean $0.53 \mathrm{~dB}$ ) for Schoenoplectus and of a maximum of $4.4 \mathrm{~dB}$ (minimum $-0.69 \mathrm{~dB}$, mean $1.5 \mathrm{~dB}$ ) for Ludwigia. Cross-polarization $\sigma^{0} \mathrm{HV}$ was always lower than co-polarization, with maximum $\sigma^{0} \mathrm{HH}-\sigma^{0} \mathrm{HV}$ differences of $17.2 \mathrm{~dB}$ (Schoenoplectus at FQ_08 scenes) and 14.6 dB (Ludwigia plots at FQ_08 and FQ_10). 


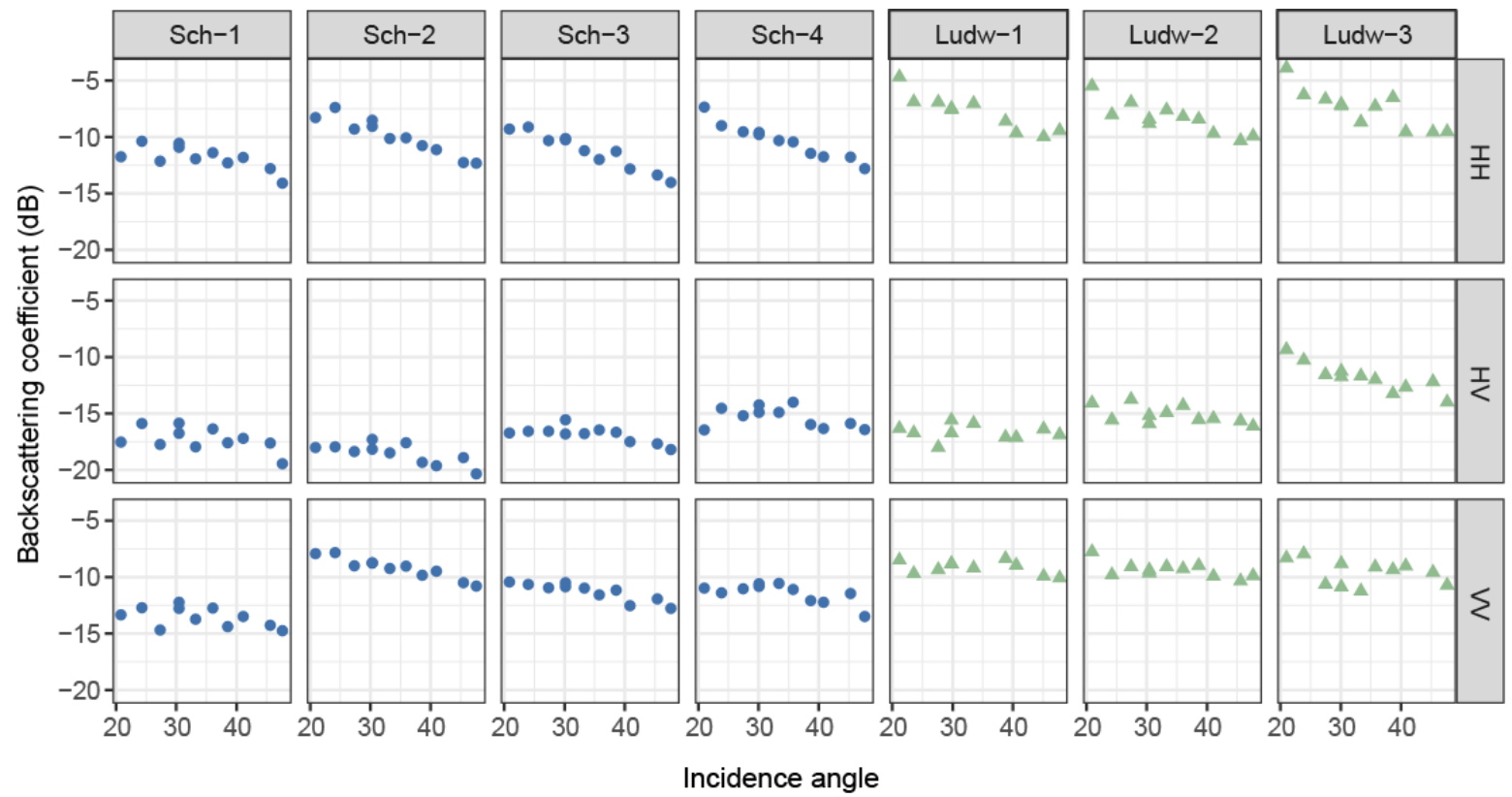

Figure 4. Median backscattering of the polygon samples in relation to incidence angle, for each target of Schoenoplectus californicus (Sch-1 to Sch-4) and Ludwigia peruviana (Ludw-1 to Ludw3), and for each polarization (HH, HV and VV). See Table 2 for detailed target descriptions. Data extracted from geocoded ground-range scenes.

\subsection{Multivariate Models on the Effect of Vegetation Features}

Generalized linear models (GLMs) show an effect of incidence angle on co-polarized backscattering, especially for $\sigma^{0} \mathrm{HH}(p<0.0001)$ : incidence angles accounted for $64.3 \%$ and $72.2 \%$ of variation of the HH backscattered power for Schoenoplectus and Ludwigia, respectively (Table 3). For $\sigma^{0} \mathrm{HV}$, emergent green biomass was the vegetation feature with higher explanatory power, accounting for $39.3 \%$ and $75.6 \%$ of the total variation in Schoenoplectus and Ludwigia targets, respectively.

Table 3. Univariate generalized linear models fitted for SAR outputs and vegetation features. For each significant model, the positive $(+)$ or negative (-) sign of the coefficient estimate is indicated, along with the $p$-value of the coefficient and its explanatory power (\%, ratio of explained deviance to null deviance). The best univariate models for each species and polarization are highlighted in bold characters. See Table 4 for multivariate models.

\begin{tabular}{|c|c|c|c|c|c|c|}
\hline \multirow{2}{*}{$\begin{array}{l}\text { Explanatory } \\
\text { Variable }\end{array}$} & \multicolumn{3}{|c|}{ Schoenoplectus californicus } & \multicolumn{3}{|c|}{ Ludwigia peruviana } \\
\hline & HH & HV & VV & HH & HV & VV \\
\hline Incidence angle & $\begin{array}{c}(-), p<0.0001 \\
64.3 \%\end{array}$ & $\begin{array}{c}(-), p=0.0213 \\
12.0 \%\end{array}$ & $\begin{array}{c}(-), p=0.0155 \\
13.2 \%\end{array}$ & $\begin{array}{c}(-), p<0.0001 \\
72.3 \%\end{array}$ & · & $\begin{array}{c}(-), p=0.0145 \\
18.3 \%\end{array}$ \\
\hline $\begin{array}{l}\text { Emergent plant } \\
\text { height }\end{array}$ & $\begin{array}{c}(+), p=0.0307 \\
10.6 \%\end{array}$ & $\begin{array}{c}(+), p=0.0005 \\
25.1 \%\end{array}$ & $\begin{array}{c}(+), p=0.0353 \\
10.1 \%\end{array}$ & $\cdot$ & $\begin{array}{c}(-), p<0.0001 \\
55.8 \%\end{array}$ & - \\
\hline $\begin{array}{l}\text { Number of } \\
\text { green stems }\end{array}$ & $\cdot$ & $\begin{array}{c}(+), p=0.0038 \\
18.2 \%\end{array}$ & · & . & $\begin{array}{c}(-), p<0.0001 \\
14.1 \%\end{array}$ & $\cdot$ \\
\hline Stem diameter & . & $\begin{array}{c}(+), p<0.0001 \\
37.5 \%\end{array}$ & $\cdot$ & $\cdot$ & $\begin{array}{c}(+), p=0.0002 \\
38.4 \%\end{array}$ & $\cdot$ \\
\hline $\begin{array}{l}\text { Emergent green } \\
\text { biomass }\end{array}$ & & $\begin{array}{c}(+), p<0.0001 \\
39.3 \%\end{array}$ & . & . & $\begin{array}{c}(+), p<0.0001 \\
75.6 \%\end{array}$ & . \\
\hline $\begin{array}{l}\text { Moisture } \\
\text { content }\end{array}$ & $\begin{array}{c}(+), p=0.0206 \\
12.1 \%\end{array}$ & $\begin{array}{c}(+), p<0.0001 \\
21.2 \%\end{array}$ & $\begin{array}{c}(+), p=0.0041 \\
18.0 \%\end{array}$ & . & . & . \\
\hline
\end{tabular}


Table 4. Multivariate generalized linear models fitted for SAR outputs and vegetation features. For each species and polarization, the best significant fitted model is summarized. Since no multivariate model was fitted for Ludwigia-VV, the univariate model is included for comparison purposes. Degrees of freedom (DF), Akaike's information criterion (AIC), and the ratio of explained deviance to null deviance (\% explained) are shown. All terms are significant $(p<0.05)$, and their $95 \%$ confidence interval does not include the zero in bootstrap permutations.

\begin{tabular}{|c|c|c|c|c|c|}
\hline Species & Polarization & Model & DF & AIC & \% Explained \\
\hline \multirow[t]{3}{*}{$\begin{array}{l}\text { Schoenoplectus } \\
\text { californicus }\end{array}$} & $\mathrm{HH}$ & $\begin{array}{l}\quad-10.83-1.29 \text { incidence angle }+0.94 \\
\text { emergent plant height }-0.57 \text { stem diameter }\end{array}$ & 40 & 103.7 & 80.6 \\
\hline & $\mathrm{HV}$ & $\begin{array}{l}-17.00-0.50 \text { incidence angle }+0.63 \text { number } \\
\text { of green stems }+0.90 \text { stem diameter }\end{array}$ & 40 & 115.2 & 68.7 \\
\hline & VV & $\begin{array}{l}-11.36-0.64 \text { incidence angle }+1.98 \\
\text { emergent plant height }-1.93 \text { stem diameter }\end{array}$ & 40 & 67.0 & 78.1 \\
\hline \multirow[t]{3}{*}{ Ludwigia peruviana } & $\mathrm{HH}$ & $\begin{array}{c}-7.88-1.34 \text { incidence angle }+0.36 \text { stem } \\
\text { diameter }\end{array}$ & 29 & 79.7 & 77.3 \\
\hline & $\mathrm{HV}$ & $\begin{array}{l}-14.46-0.57 \text { incidence angle }+1.96 \\
\text { emergent green biomass }-0.43 \text { interaction } \\
\text { (biomass:incidence angle) }\end{array}$ & 28 & 90.8 & 85.2 \\
\hline & VV & $-9.38-0.35$ incidence angle & 30 & 77.1 & 18.3 \\
\hline
\end{tabular}

Multivariate GLMs that included scene incidence angle and vegetation features show high explanatory power for most single polarization backscattering coefficients (Table 4), except for Ludwigia- $\sigma^{0} \mathrm{vv}$ for which no multivariate model was fitted. Besides the aforementioned effect of incidence angle, co-polarized backscattering of Schoenoplectus targets increases with emergent plant height and decreases with stem diameter; whereas crosspolarized backscattering increases with the number of green stems and stem diameters. In Ludwigia targets, $\sigma^{0} \mathrm{HH}$ increases with stem diameters, and cross-polarized backscattering increases with emergent green biomass.

\subsection{Phase Difference Analyses}

A total of 75 CPD and XPD distributions were analyzed, each corresponding to a target site on a given scene (with scenes differing on their incidence angles).

Figure 5 shows the $\psi_{0}$ value of the CPD distribution of the four Schoenoplectus and three Ludwigia targets, extracted using the MLE technique (Equation (2)).
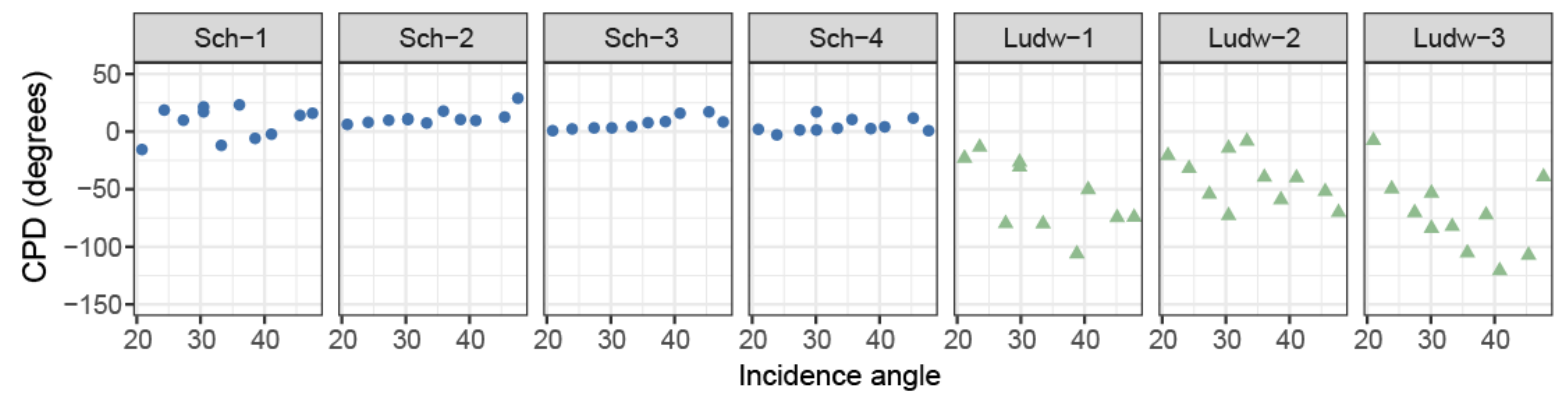

Figure 5. Co-polarized phase differences $\varphi_{\mathrm{HH}}-\varphi_{\mathrm{VV}}(\mathrm{CPD})$ of the targets according to the Maximum Likelihood Estimation technique. Target descriptions are given in Table 2. Data extracted on SLC scenes.

The CPD values observed in the histograms we analyzed can result from singlebounce, double-bounce, or multiple-scattering [17]. Single-bounce backscatter always produces CPD values near zero degrees, but with a probability distribution given by Equation (2). Double-bounce backscatter can produce high, intermediate, or low CPD values degrees $[14,17,26]$, depending on the moisture content, size, and geometry of the vegetation. 
Multiple scattering produces a random distribution of CPD, forming a "pedestal" in the histogram, above which one or two peaks are often found [26].

In Figure 5 we observe that the peaks for Schoenoplectus are always centered near zero degrees, independent of incidence angle: CPD ranged between $-15.32^{\circ}$ and $29.04^{\circ}$ and the coherence ranged between 0.11 and 0.70 . The high values of moisture content (Table 2), together with recent modelling work [17], rule out the possibility of doublebounce backscatter from these stands. The histograms used to extract the mode CPD values indicate that the signal is dominated by single-bounce backscatter, with a small amount of multiple scattering. At steep incidence angles the single-bounce backscatter could come from a combination of backscatter from the plants and backscatter from the water and floating vegetation. At shallower incidence angles, most of the backscatter is expected to come from the plants.

The CPD values observed for Ludwigia (Figures 5 and 6) show evidence of doublebounce backscatter, especially at larger incidence angles. CPD ranged between $-120.57^{\circ}$ and $7.65^{\circ}$ and the coherence ranged between 0.08 and 0.46 . The histograms also show evidence of single-bounce backscatter and multiple scattering. In Figure 6, the maximum likelihood estimations of the CPD distribution are shown for the four samples with CPD values significantly lower than zero. As can be seen in the photographs (Figure 2), vegetation targets have rotational symmetry, i.e., vertical stems have random orientation angles and not a dominant orientation. Consistently, none of the cross-polarization phase distributions showed fitted XPD values significantly different from zero.
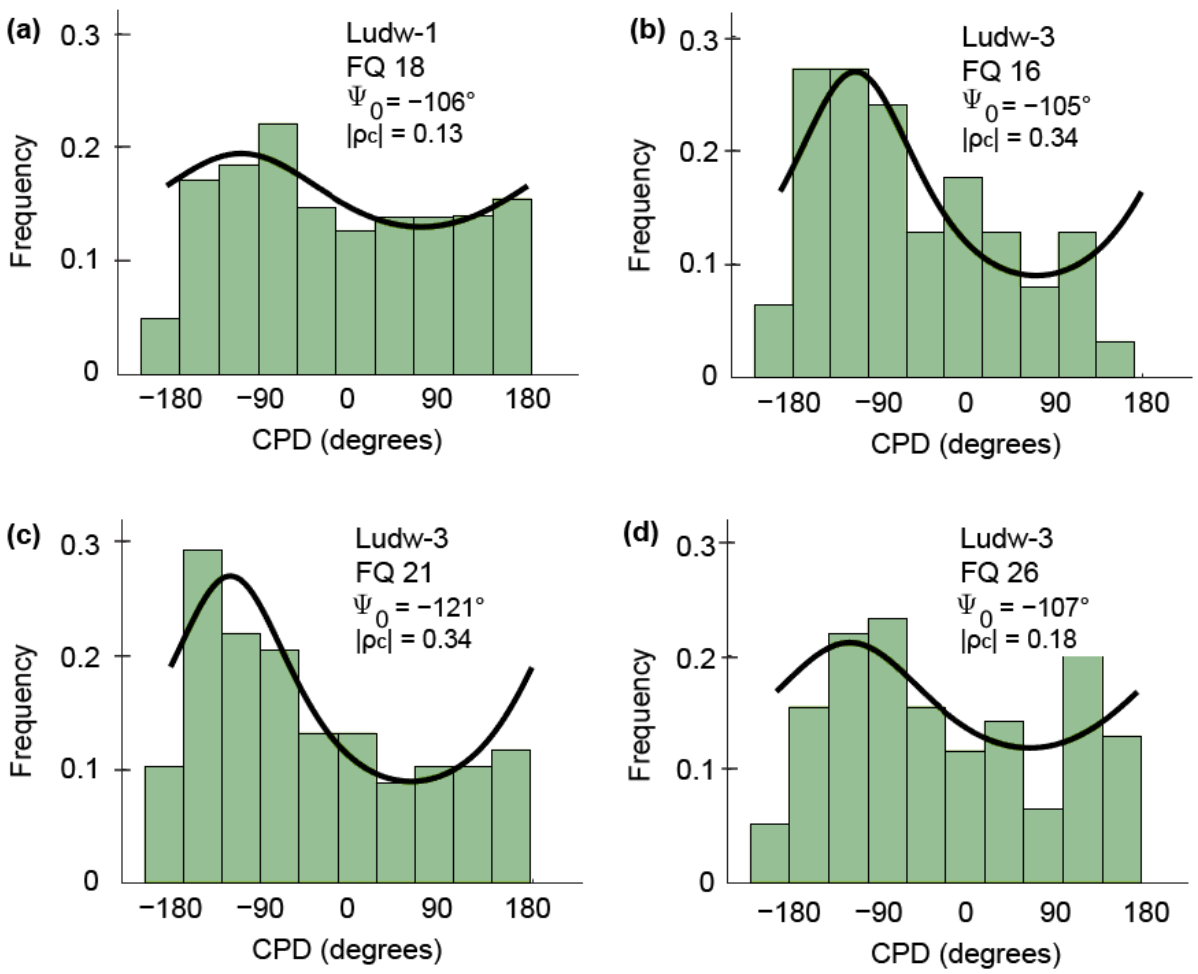

Figure 6. Maximum likelihood estimations of co-polarized phase difference (CPD) $\psi_{0}$, for CPD values significantly lower than zero. The $\psi_{0}$ estimations were obtained with Equation (2). Coherence is notated $\left|\rho_{c}\right|$. Each subfigure shows a sampling site (see Table 2 for target description) and scene beam ordered by increasing incidence angle (see Table 1). (a) Ludw-1, FQ 18; (b) Ludw-3, FQ 16; (c) Ludw-3, FQ 21; (d) Ludw-3, FQ 26.

\section{Discussion}

The use of SAR data in wetlands provides valuable information to assess flooding and monitor vegetation changes [8,9]. Here, we studied two of the typical marsh communities of the Lower Paraná River floodplain, dominated by Bulrush marshes and Broadleaf 
marshes. In the presence of water below vegetation, the contribution of double-bounce scatter can enhance the backscattered return, be responsible for $\sigma^{0}{ }_{\mathrm{HH}}$ greater than $\sigma^{0} \mathrm{VV}$, and produce high co-polarized phase differences (CPD) [22]. However, this response depends on the signal frequency, on the scene incidence angle and on vegetation features: our results with RADARSAT-2 C-band data highlight that even in the presence of water, double-bounce can be negligible for dense herbaceous targets or may only be detected at certain incidence angles.

Differences between $\sigma^{0} \mathrm{HH}$ and $\sigma^{0} \mathrm{VV}$, especially at steep incidence angles, were previously described for Schoenoplectus species in flooded temperate wetlands $[15,56]$. The differential behavior between polarizations in flooded vegetated areas at steeper incidence angles has been reported in other studies accounting for multi-incidence scenes (e.g., [56], which interpreted that double-bounce may be occurring but have not explored that hypothesis). Grings et al. 2005 have conducted electromagnetic simulation models for Schoenoplectus californicus based on radiative transfer theory [15], and predicted strong differences between simulated C-band $\sigma^{0} \mathrm{HH}$ and $\sigma^{0} \mathrm{Vv}$ temporal trends. Our Schoenoplectus sites can be compared to the mature marshes in the cited model [15]: dense, partially dry, and with loss of vertical orientation (see Table 2 and photographs in Figure 2). The dominating processes in these flooded targets would be: 1) cylinder bistatic specular scattering, higher in $\mathrm{H}$ incident polarization than in $\mathrm{V}$; and 2) shoot attenuation (extinction coefficient) higher at $\mathrm{V}$ than at $\mathrm{H}[15,16]$. Our CPD results do not evidence the occurrence of double-bounce scatter in Schoenoplectus targets, and the observed $\sigma^{0} \mathrm{HH}^{-\sigma^{0}} \mathrm{VV}$ differences are relatively low in comparison with results obtained when the double Brewster angle effect was reported and modeled [25]. Efforts in model improvements for Schoenoplectus californicus should aim at better modeling the stem structure by considering its non-cylindrical shape and the dielectric properties of aerenchyma tissues (see photograph in Figure 2d).

To our knowledge, no radiative transfer models have been conducted for Ludwigia peruviana or for a similar broadleaf emergent macrophyte. Ludwigia spp. models (or similar broad-leaf herbaceous species) are not available at the moment. We suggest that radiative transfer models for this species include cylinders (stems) and disks (leaves), and should contemplate that a portion of the plant individuals have hollow stems, as was reported for the Lower Paraná River floodplain [57]. For both Ludwigia and Schoenoplectus, accounting for stem tilting would help to simulate co-polarized phase differences accurately [17]. These model improvements may contribute to better-estimating phase differences and/or backscattering powers. Additionally, future models need to include full polarimetric analyses and predict phase difference changes.

Scene incidence angles had the most significant effect on $\sigma^{0} \mathrm{HH}$ and explained a portion of the variations on $\sigma^{0} \mathrm{HV}$ and $\sigma^{0} \mathrm{VV}$. This result is in accordance with the literature: signal attenuation increases with incidence angle [11], because of a higher wave-vegetation interaction and less penetration that leads to changes in the backscatter mechanism [58,59]. Based on this SAR signal behavior, several studies recommend using steep incidence angle scenes for flood monitoring and shallow incidence angles for better discrimination of herbaceous vegetation types $[9,31]$. Using multi-incidence angle scenes close in time provides optimum flood monitoring and vegetation type discrimination $[56,60]$. Our results also demonstrate that integrating different scene configurations including incidence angle benefits target discrimination, but also enhance the detection of double-bounce scatter, especially in dense herbaceous targets. The combined use of polarimetric data and interferometry (in search of phase change "fringes") would improve flood detection [22,23].

Volume scatter seems to be the main interaction mechanism contributing to the backscattered return in the dense herbaceous targets of the Lower Paraná River floodplain. The general pattern was similar at sites dominated by the two addressed species: a strong effect of scene incidence angles and vegetation features. However, backscattering coefficients were higher for Ludwigia than for Schoenoplectus targets, suggesting that their different architectures and vegetation distribution within the plot affect C-band SAR-target interaction [31]. The effect of incidence angle on co-polarized backscattering coefficients 
was higher in Ludwigia targets, and steep angles maximized the differences between these two vegetation types. The fitted generalized linear models highlight the effect of vegetation features for all polarizations. The response of C-band co-polarized signal to vegetation features of herbaceous vegetation has been widely reported in previous studies $[9,16,61]$. Here, emergent green biomass was strongly related to $\sigma^{0} \mathrm{HV}$ in Ludwigia sites, whereas the best model for $\sigma^{0} \mathrm{HV}$ in Schoenoplectus sites included the number of green stems and stem diameters.

Evidence consistent with double-bounce scatter was found on two of the Ludwigia sites, based on the CPD maximum likelihood estimations. These flooded Ludwigia targets were dense and showed high moisture content (75-80\%), but their emergent green biomass was lower than in Schoenoplectus targets (Table 2). Most notably, Ludwigia targets differed both in plant architecture and in the absence of dry stems, typical of mature Schoenoplectus targets [15]. Double-bounce scatter was expected to vary as a function of the incidence angle [22] because of changes in the Fresnel reflection coefficients $[14,21,25,26]$. However, our results are not conclusive in support of this hypothesis, probably because of the targets high biomass: a trade-off between increasing contribution of double-bounce scatter and signal attenuation by the biomass has been reported [62].

The scenes which allowed double-bounce scatter to be detected had intermediate to shallow scene incidence angles $\left(36.2^{\circ}\right.$ to $\left.45.1^{\circ}\right)$ and not steep angles. Thus, our approach with CPD maximum likelihood estimations can be useful as an indicator of double-bounce scatter, but scenes from contrasting incidence angles should be assessed. Although Cband can detect water presence in marshes, this is hindered with increasing plant cover and LAI [63]. In these cases, L-band signals may still penetrate through vegetation and double-bounce may happen when interacting with water and stems [9]. Cross-polarized phase differences (XPD) were not informative of the presence of double-bounce in the addressed targets, which is consistent with the lack of a dominant orientation in the stems of Schoenoplectus and Ludwigia (cf. results reported for urban and forest targets [30,64]).

Modeling the phase would provide new insights on wave-vegetation interaction. A dedicated model was proposed by Ulaby et al. (1987) [21]. It computes the co-polarized phase difference by considering the vegetation as a collection of randomly distributed vertical lossy cylinders over a dielectric half-space. Besides plant structure parameters such as diameter and height, the model requires the dielectric constant of the stems. Since this is a parameter that is difficult to measure, models computing bulk vegetation dielectric properties from vegetation moisture are available, being the Mätzler 1994 model [65] suitable for large moisture contents such as those found in the Schoenoplectus and Ludwigia sites (ranging between $62 \%$ and $80 \%$ on a weight basis). Although the model proposed by Ulaby et al. (1987) [21] was first validated on corn fields imaged at L-band, we found this model is not sensitive to the co-polarized phase difference resulting from the dielectric features presented in the study site (results not shown). More research is needed to model CPD for these herbaceous targets.

The two studied species dominate Bulrush marshes and Broadleaf marshes in the Lower Paraná River floodplain (mainly in the Middle Delta) [33], and are relevant for the ecosystem functioning of the freshwater wetlands of the area and for the regional economy. Due to the high biomass and coverage of these species, using optical data usually does not allow the detection of water, as has been described for other dense herbaceous vegetation targets $[6,7,13]$. However, the use of optical data combined with SAR data may improve both the discrimination of the vegetation types and the detection of water. For example, a previous study in the Paraná floodplain used SAC-C optical data to derive a land cover map and C-band ENVISAT ASAR data to estimate marsh plant density in burnt areas [66]. Applications with hyperspectral data have been poorly addressed in South American wetlands because of the restricted availability and expensive acquisition of these imageries [3], but have been used to map the invasion of Ludwigia spp. into Schoenoplectus californicus marshes in California, United States [67]. Besides, passive microwave data has been used to assess floods in the Paraná River floodplain [68], but the low spatial 
resolution limits the use of these data to discriminate vegetation types or monitor flooding at a detailed scale.

In regard to SAR data, based on the results of this study we suggest involving multiincidence angle scenes, or at least using two contrasting incidence angles, one steep and one shallow. The combined use of C-band and L-band data may help to better account for dense herbaceous targets: C-band backscattering would depend on vegetation features-as is described here-, and the L-band signal may still penetrate through herbaceous vegetation and detect the presence of surface water [9]. These recommendations may be useful not only for the Lower Paraná River floodplain but also for other areas of the Paraná floodplain $[69,70]$ or other South American wetlands where these macrophytes can cover large areas. Bulrush marshes dominated by Schoenoplectus californicus are also typical of temperate wetlands in North America [71]. Besides, Ludwigia spp. behaves as an invasive species in North America [67] and South-West Europe [71], with a great impact on the ecosystem functioning of the natural marshes. Monitoring the state of Schoenoplectus spp. and Ludwigia spp. marshes and their changes due to flooding, phenology, fires or other anthropic impacts (or invasive spreading in the Northern Hemisphere) can improve the understanding of the ecological dynamics of freshwater wetlands.

\section{Conclusions}

Here, we assessed flooded herbaceous targets from two species, which are expected to have significant double-bounce scatter, with RADARSAT-2 C-band fully polarimetric scenes acquired at several incidence angles. Incidence angles and vegetation features explain most of the variability in backscattered power. This study provides an example of using co-polarized phase differences to decide on the contribution of double-bounce scatter in a temperate freshwater wetland and with herbaceous targets. Our results emphasize the need to be cautious with flood monitoring conclusions, since obtaining no evidence of double-bounce scatter with a particular scene does not indicate the absence of water. Indeed, we suggest using multi-incidence angle scenes or at least comparing two different beams before deciding on the contribution of double-bounce scatter. Due to the high effect of vegetation features on backscattered power, studies conducted during a growing season need to address plant height, stem density, and biomass changes. The assessment of these dense marshes could also be improved with L-band full polarimetric data (such as those from ALOS-2/PALSAR-2 and SAOCOM-1A and 1B missions) because of the higher penetration and less signal attenuation.

Author Contributions: Conceptualization, N.S.M., M.E.B., F.A., and B.B.; methodology, N.S.M. and M.E.B.; field sampling, N.S.M. and P.K.; field sampling design, N.S.M., F.M.G., and P.K.; data curation, visualization and data analyses, N.S.M. and M.E.B.; writing—original draft preparation, N.S.M. and M.E.B.; writing-review and editing, N.S.M., M.E.B., F.M.G., F.A., P.K., and B.B.; funding acquisition, P.K. and N.S.M.; imagery acquisition agreements, N.S.M., B.B., and P.K. All authors have read and agreed to the published version of the manuscript.

Funding: This research was funded by the Agencia Nacional de Promoción de la Investigación, el Desarrollo Tecnológico y la Innovación, grant numbers 2017-1256 (PI N.S.M.) and 2014-0824 (PI P.K.). RADARSAT-2 scenes were acquired with a Multi-User Agreement of MDA's Geospatial Services (PI B.B.). SPOT scenes were acquired thanks to an agreement between Comisión Nacional de Actividades Espaciales and Universidad Nacional de San Martín (PI P.K.). A 10-days stay of N.S.M. in Canada was partially funded by the Universidad Nacional de San Martín and allowed meetings with B.B. and F.A., as well as the presentation of preliminary results at the ASAR Workshop 2019 (1-3 October 2019, Canadian Space Agency).

Institutional Review Board Statement: Not applicable.

Informed Consent Statement: Not applicable.

Data Availability Statement: Data available on request from the corresponding author. The data are not publicly available due to license restrictions. 
Acknowledgments: We thank Luis Bello, Tino Bello, and their families for their valuable help during fieldwork in the islands and for allowing us to camp beside their houses. Daniel Zanola Escalante and Maira Gayol helped with fieldwork. The Instituto Nacional del Agua provided hydrometric data, and we thank Martín Sabarots Gerbec. The Servicio Metereológico Nacional provided precipitation and wind data. We thank Laetitia Thirion-Lefevre for her valuable feedback on preliminary results of this study, presented at the ASAR Workshop 2019 (Canadian Space Agency). We are also grateful to three anonymous reviewers that contributed with their comments and suggestions.

Conflicts of Interest: The authors declare no conflict of interest. The funders had no role in the design of the study; in the collection, analyses, or interpretation of data; in the writing of the manuscript, or in the decision to publish the results.

\section{References}

1. Junk, W.J.; An, S.; Finlayson, C.M.; Gopal, B.; Květ, J.; Mitchell, S.A.; Mitsch, W.J.; Robarts, R.D. Current state of knowledge regarding the world's wetlands and their future under global climate change: A synthesis. Aquat. Sci. 2013, 75, 151-167. [CrossRef]

2. Neiff, J.J.; Malvárez, A.I. Grandes Humedales Fluviales. In Documentos del Curso-Taller Bases Ecológicas Para la Clasificación e Inventario de Humedales en Argentina; Malvárez, A.I., Bó, R.F., Eds.; Ana Inés Malvárez editora: Buenos Aires, Argentina, $2004 ;$ pp. 77-85.

3. Kandus, P.; Minotti, P.G.; Morandeira, N.S.; Grimson, R.; González Trilla, G.; González, E.B.; San Martin, L.; Gayol, M.P. Remote sensing of wetlands in South America: Status and challenges. Int. J. Remote. Sens. 2017, 39, 993-1016. [CrossRef]

4. Junk, W.J.; Bayley, P.B.; Sparks, R.E. The flood pulse concept in river-floodplain systems. Can. Spec. Publ. Fish. Aquat. Sci. 1989, $106,110-127$.

5. Neiff, J.J.; Malvárez, A.I. El Régimen de Pulsos en Ríos y Grandes Humedales de Sudamérica. In Tópicos sobre Humedales Subtropicales y Templados de Sudamérica; Malvárez, A.I., Ed.; UNESCO: Montevideo, Uruguay, 1999; pp. 99-150.

6. Silva, T.S.F.; Costa, M.P.F.; Melack, J.M.; Novo, E.M.L.M. Remote sensing of aquatic vegetation: Theory and applications. Environ. Monit. Assess. 2008, 140, 131-145. [CrossRef] [PubMed]

7. Jakubauskas, M.; Kindscher, K.; Fraser, A.; Debinski, D.; Price, K.P. Close-range remote sensing of aquatic macrophyte vegetation cover. Int. J. Remote. Sens. 2000, 21, 3533-3538. [CrossRef]

8. Brisco, B. Mapping and Monitoring Surface Water and Wetlands with Synthethic Aperture Radar. In Remote Sensing of Wetlands: Applications and Advances; Tiner, R.W., Lang, M.W., Klemas, V.V., Eds.; CRC Press: Boka Raton, FL, USA, 2015 ; p. 119.

9. Henderson, F.M.; Lewis, A.J. Radar detection of wetland ecosystems: A review. Int. J. Remote. Sens. 2008, 29, 5809-5835. [CrossRef]

10. Van Zyl, J. Unsupervised classification of scattering behavior using radar polarimetry data. IEEE Trans. Geosci. Remote. Sens. 1989, 27, 36-45. [CrossRef]

11. Kasischke, E.S.; Melack, J.M.; Dobson, M.C. The use of imaging radars for ecological applications-A review. Remote. Sens. Environ. 1997, 59, 141-156. [CrossRef]

12. Wang, Y.; Hess, L.L.; Filoso, S.; Melack, J.M. Understanding the radar backscattering from flooded and nonflooded Amazonian forests: Results from canopy backscatter modeling. Remote. Sens. Environ. 1995, 54, 324-332. [CrossRef]

13. Hess, L.L.; Melack, J.M.; Novo, E.M.; Barbosa, C.C.; Gastil, M. Dual-season mapping of wetland inundation and vegetation for the central Amazon basin. Remote. Sens. Environ. 2003, 87, 404-428. [CrossRef]

14. Ahern, F.; Brisco, B.; Murnaghan, K.; Lancaster, P.; Atwood, D.K. Insights into Polarimetric Processing for Wetlands from Backscatter Modeling and Multi-Incidence Radarsat-2 Data. IEEE J. Sel. Top. Appl. Earth Obs. Remote. Sens. 2018, 11, 3040-3050. [CrossRef]

15. Grings, F.; Ferrazzoli, P.; Karszenbaum, H.; Tiffenberg, J.; Kandus, P.; Guerriero, L.; Jacobo-Berrles, J. Modeling temporal evolution of junco marshes radar signatures. IEEE Trans. Geosci. Remote. Sens. 2005, 43, 2238-2245. [CrossRef]

16. Grings, F.; Ferrazzoli, P.; Jacobo-Berlles, J.; Karszenbaum, H.; Tiffenberg, J.; Pratolongo, P.; Kandus, P. Monitoring flood condition in marshes using EM models and Envisat ASAR observations. IEEE Trans. Geosci. Remote. Sens. 2006, 44, 936-942. [CrossRef]

17. Ahern, F.; Brisco, B.; Battaglia, M.; Atwood, D.; Bourgeau-Chavez, L.L.; Murnaghan, K. Understanding polarimetric SAR backscatter from wetlands through cylinder modelling. Remote Sens.. Under Review.

18. Skriver, H.; Svendsen, M.; Thomsen, A. Multitemporal C- and L-band polarimetric signatures of crops. IEEE Trans. Geosci. Remote. Sens. 1999, 37, 2413-2429. [CrossRef]

19. Balenzano, A.; Mattia, F.; Satalino, G.; Davidson, M.W.J. Dense Temporal Series of C- and L-band SAR Data for Soil Moisture Retrieval Over Agricultural Crops. IEEE J. Sel. Top. Appl. Earth Obs. Remote. Sens. 2011, 4, 439-450. [CrossRef]

20. Ulaby, F.T.; Long, D.G. Microwave Radar and Radiometric Remote Sensing; The University of Michigan Press: Ann Arbor, MI, USA, 2014.

21. Ulaby, F.T.; Held, D.; Donson, M.C.; McDonald, K.C.; Senior, T.B.A. Relating Polaization Phase Difference of SAR Signals to Scene Properties. IEEE Trans. Geosci. Remote. Sens. 1987, GE-25, 83-92. [CrossRef]

22. Brisco, B.; Ahern, F.; Hong, S.-H.; Wdowinski, S.; Murnaghan, K.; White, L.; Atwood, D.K. Polarimetric Decompositions of Temperate Wetlands at C-Band. IEEE J. Sel. Top. Appl. Earth Obs. Remote. Sens. 2015, 8, 3585-3594. [CrossRef]

23. Hong, S.-H.; Wdowinski, S. Double-Bounce Component in Cross-Polarimetric SAR From a New Scattering Target Decomposition. IEEE Trans. Geosci. Remote. Sens. 2014, 52, 3039-3051. [CrossRef] 
24. Atwood, D.K.; Matthiss, B.; Jenkings, L.K.; Wdowinski, S.; Hong, S.-H. Wave propagation model for coherent scattering from a randomly distributed target. In Proceedings of the 6th International Workshop on Science and Applications of SAR Polarimetry and Polarimetric Interferometry, Frascati, Italy, 28 January-1 February 2013; pp. 1-7.

25. Thirion-Lefevre, L.; Guinvarc'H, R. The double Brewster angle effect. Comptes Rendus Phys. 2018, 19, 43-53. [CrossRef]

26. Atwood, D.; Battaglia, M.; Bourgeau-Chavez, L.; Ahern, F.; Murnaghan, K.; Brisco, B. Exploring Polarimetric Phase of Microwave Backscatter from Typha Wetlands. Can. J. Remote. Sens. 2020, 46, 49-66. [CrossRef]

27. Richards, J.A. Remote Sensing with Imaging Radar; Springer Science and Business Media LLC: Berlin/Heidelberg, Germany, 2009.

28. Freeman, A.; Durden, S. A three-component scattering model for polarimetric SAR data. IEEE Trans. Geosci. Remote. Sens. 1998, 36, 963-973. [CrossRef]

29. Yamaguchi, Y.; Yajima, Y.; Yamada, H. A Four-Component Decomposition of POLSAR Images Based on the Coherency Matrix. IEEE Geosci. Remote. Sens. Lett. 2006, 3, 292-296. [CrossRef]

30. Atwood, D.K.; Thirion-Lefevre, L. Polarimetric Phase and Implications for Urban Classification. IEEE Trans. Geosci. Remote. Sens. 2018, 56, 1278-1289. [CrossRef]

31. Morandeira, N.S.; Grings, F.; Facchinetti, C.; Kandus, P. Mapping Plant Functional Types in Floodplain Wetlands: An Analysis of C-Band Polarimetric SAR Data from RADARSAT-2. Remote. Sens. 2016, 8, 174. [CrossRef]

32. Grimson, R.; Morandeira, N.S.; Gayol, M.P.; Kandus, P. Freshwater marsh classification in the Lower Paraná River floodplain: An object-based approach on multitemporal X-band COSMO-SkyMed data. J. Appl. Remote. Sens. 2019, 13, 014531. [CrossRef]

33. Morandeira, N.S.; Kandus, P. Multi-scale analysis of environmental constraints on macrophyte distribution, floristic groups and plant diversity in the Lower Paraná River floodplain. Aquat. Bot. 2015, 123, 13-25. [CrossRef]

34. Enrique, C. Relevamiento y Caracterización Florística y Espectral de los Bosques de la Región del Delta del Paraná a Partir de Imágenes Satelitales. Bachelor's Thesis, Facultad de Ciencias Exactas y Naturales, Universidad de Buenos Aires, Buenos Aires, Argentina, 2009.

35. Borro, M.M.; Morandeira, N.S.; Salvia, M.M.; Minotti, P.G.; Perna, P.; Kandus, P. Mapping shallow lakes in a large South American floodplain: A frequency approach on multitemporal Landsat TM/ETM data. J. Hydrol. 2014, 512, 39-52. [CrossRef]

36. Morandeira, N.S.; Kandus, P. Do taxonomic, phylogenetic and functional plant $\alpha$ - and $\beta$-diversity reflect environmental patterns in the Lower Paraná River floodplain? Plant Ecol. Divers. 2017, 10, 153-165. [CrossRef]

37. Baigún, C.R.M.M.; Puig, A.; Minotti, P.G.; Kandus, P.; Quintana, R.D.; Vicari, R.L.; Bó, R.F.; Oldani, N.O.; Nestler, J.A. Resource use in the Parana River Delta (Argentina): Moving away from an ecohydrological approach? Ecohydrol. Hydrobiol. 2008, 8 , 245-262. [CrossRef]

38. Gurini, L.; Basilio, A.M. Flora apícola en el Delta del Paraná. Darwiniana 1995, 33, 337-346.

39. McCarthy, B.C.; Magurran, A.E. Measuring Biological Diversity; Blackwell Science: Malden, MA, USA, 2004.

40. Sartori, L.R.; Imai, N.; Mura, J.C.; Novo, E.M.L.D.M.; Silva, T. Mapping Macrophyte Species in the Amazon Floodplain Wetlands Using Fully Polarimetric ALOS/PALSAR Data. IEEE Trans. Geosci. Remote Sens. 2011, 49, 4717-4728. [CrossRef]

41. Caves, R.; Williams, D. Geolocation of RADARSAT-2 georeferenced products. RADARSAT-2. Appl. Tech. Note 2015, RN-TN-53-0, 1-25.

42. European Space Agency. PolSARpro. V. 5.0. Available online: http:/ / earth.eo.esa.int/polsarpro/ (accessed on 23 April 2019).

43. European Space Agency. SNAP-ESA Sentinel Application Platform v8. Available online: http:/ / step.esa.int (accessed on 23 April 2019).

44. Zuur, A.; Ieno, E.N.; Walker, N.; Saveliev, A.A.; Smith, G.M. Mixed Effects Models and Extensions in Ecology with R; Springer Science \& Business Media: New York, NY, USA, 2009.

45. López-Martínez, C.; Fabregas, X. Polarimetric sar speckle noise model. IEEE Trans. Geosci. Remote Sens. 2003, 41, $2232-2242$. [CrossRef]

46. Wasserman, L. All of Statistics: A Concise Course in Statistical Inference; Springer Science \& Business Media: Berlin/Heidelberg, Germany, 2013; ISBN 9780387217369.

47. Davison, A.C.; Hinkley, D.V. Bootstrap Methods and Their Applications; Cambridge University Press: Cambridge, UK, 1997.

48. Zuur, A.F.; Ieno, E.N.; Elphick, C.S. A protocol for data exploration to avoid common statistical problems. Methods Ecol. Evol. 2010, 1, 3-14. [CrossRef]

49. R Core Team. R: A Language and Environment for Statistical Computing. 2020. Available online: https://www.r-project.org/ (accessed on 22 May 2020).

50. Wickham, H.; François, R.; Henry, L.; Müller, K. dplyr: A Grammar of Data Manipulation. 2020. Available online: https: / / cran.r-project.org/web/packages/dplyr/index.html (accessed on 22 May 2020).

51. Wickham, H.; Henry, L. Tidyr: Tidy Messy Data. 2020. Available online: https://cran.r-project.org/web/packages/tidyr/index. html (accessed on 22 May 2020).

52. Wickham, H. ggplot2: Elegant Graphics for Data Analysis; Springer: New York, NY, USA, 2016; ISBN 978-3-319-24277-4.

53. Zeileis, A.; Hothorn, T. Diagnostic Checking in Regression Relationships. R News 2002, 2, 7-10.

54. Fox, J.; Weisberg, S. An \{R\} Companion to Applied Regression, 3rd ed.; Sage: Thousand Oaks, CA, USA, 2019.

55. Canty, A.; Ripley, B.D. Boot: Bootstrap R (S-Plus) Functions. 2020. Available online: https://cran.r-project.org/web/packages/ boot/index.html (accessed on 22 May 2020).

56. Marti-Cardona, B.; López-Martínez, C.; Dolz-Ripolles, J.; Bladè-Castellet, E. ASAR polarimetric, multi-incidence angle and multitemporal characterization of Doñana wetlands for flood extent monitoring. Remote Sens. Environ. 2010, 114, $2802-2815$. [CrossRef] 
57. Morandeira, N.S.; Kandus, P. Plant functional types and trait values in the Paraná River floodplain: Modelling their association with environmental features. Flora Morphol. Distrib. Funct. Ecol. Plants 2016, 220, 63-73. [CrossRef]

58. Adeli, S.; Salehi, B.; Mahdianpari, M.; Quackenbush, L.; Brisco, B.; Tamiminia, H.; Shaw, S. Wetland Monitoring Using SAR Data: A Meta-Analysis and Comprehensive Review. Remote Sens. 2020, 12, 2190. [CrossRef]

59. Dabboor, M.; Brisco, B. Wetland Monitoring and Mapping Using Synthetic Aperture Radar. In Wetlands Management-Assessing Risk and Sustainable Solutions; Gokce, D., Ed.; IntechOpen: London, UK, 2020; pp. 61-86.

60. Kandus, P.; Karszenbaum, H.; Pultz, T.; Parmuchi, G.; Bava, J. Influence of Flood Conditions and Vegetation Status on the Radar Backscatter of Wetland Ecosystems. Can. J. Remote. Sens. 2001, 27, 651-662. [CrossRef]

61. Novo, E.D.M.; Costa, M.D.F.; Mantovani, J. RADARSAT Exploratory Survey on Macrophyte Biophysical Parameters in Tropical Reservoirs. Can. J. Remote. Sens. 1998, 24, 367-375. [CrossRef]

62. Karszenbaum, H.; Kandus, P.; Martinez, J.M.; Le Toan, T.; Tiffenberg, J.; Parmuchi, G. ERS-2, RADARSAT SAR backscattering characteristics of the Paraná River Delta wetland, Argentina. In Proceedings of the ERS-ENVISAT Symposium. Looking down to Earth in the New Millennium, Gothenburg, Sweden, 16-20 October 2000; pp. 1-10.

63. Ramsey, E., III. Radar remote sensing of wetlands. In Remote Sensing Change Detection: Environmental Monitoring Methods and Applications; Lunetta, R., Elviidge, C., Eds.; Ann Harbor Press: Chelsea, MA, USA, 1998; pp. 211-243.

64. Thirion-Lefevre, L.; Guinvarc'H, R.; Colin-Koeniguer, E. Comparative Analysis of the Relative Polarimetric Radar Signature of Vegetation and Cities Districts. In Proceedings of the International Geoscience and Remote Sensing Symposium, Yokohama, Japan, 28 July-2 August 2019; IEEE: Piscataway, NJ, USA, 2019; pp. 5221-5223.

65. Matzler, C. Microwave (1-100 GHz) dielectric model of leaves. IEEE Trans. Geosci. Remote. Sens. 1994, 32, 947-949. [CrossRef]

66. Salvia, M.; Franco, M.; Grings, F.; Perna, P.; Martino, R.; Karszenbaum, H.; Ferrazzoli, P. Estimating Flow Resistance of Wetlands Using SAR Images and Interaction Models. Remote. Sens. 2009, 1, 992-1008. [CrossRef]

67. Khanna, S.; Santos, M.J.; Boyer, J.D.; Shapiro, K.D.; Bellvert, J.; Ustin, S.L. Water primrose invasion changes successional pathways in an estuarine ecosystem. Ecosphere 2018, 9, 1-18. [CrossRef]

68. Salvia, M.; Grings, F.; Barraza, V.; Perna, P.; Karszenbaum, H.; Feirazzoli, P. Active and passive microwave systems in the assessment of flooded area fraction and mean water level in the Paraná River floodplain. In Proceedings of the 12th Specialist Meeting on Microwave Radiometry and Remote Sensing of the Environment (MicroRad), Rome, Italy, 5-9 March 2012; pp. 1-4.

69. Neiff, J.J.; Casco, S.L.; Mari, E.K.A.; Di Rienzo, J.A.; Poi, A.S. Do aquatic plant assemblages in the Paraná River change along the river's length? Aquat. Bot. 2014, 114, 50-57. [CrossRef]

70. Marchetti, Z.Y.; Aceñolaza, P.G. Vegetation communities and their relationship with the pulse regime on islands of the Middle Parana River, Argentina. Iheringia Ser. Bot. 2011, 66, 209-225.

71. Hussner, A. Growth response and root system development of the invasive Ludwigia grandiflora and Ludwigia peploides to nutrient availability and water level. Fundam. Appl. Limnol. 2010, 177, 189-196. [CrossRef] 